\author{
Bolesław Goranczewski \\ Wrocław School of Banking \\ Faculty of Economics in Opole \\ b.goranczewski@wsb.wroclaw.pl \\ Daniel Puciato \\ Opole University of Technology \\ Institute of Tourism and Leisure \\ d.puciato@po.opole.pl
}

\title{
SWOT ANALYSIS IN THE FORMULATION OF TOURISM DEVELOPMENT STRATEGIES FOR DESTINATIONS
}

\begin{abstract}
The aim of the paper is to identify the role of SWOT analysis in the formulation of tourism development strategies for destinations. SWOT analysis helps to establish a reliable diagnosis of the internal potential shown by a tourism destination and its environment. In the Polish economic situation, SWOT analysis is frequently used in a fragmentary manner which should be considered as a serious methodological oversight and may jeopardize the value of the entire process related to the strategic management of the tourism destination.
\end{abstract}

Key words: strategic management, SWOT analysis, tourism development strategy, destination.

\section{INTRODUCTION}

The dynamic growth of leisure travel and related tourism expenditure has now turned tourism into a mass phenomenon. Quantitative trends are accompanied by qualitative ones which include, above all, technological progress, particularly in the fields of transport and IT technologies, liberalization of international economic relations and the regionalization of the world. In practical terms, this means a wider offer for an average consumer and tougher competition among entities representing the supply side of tourism (DZIEDZIC 1998). Due to the unique character of the spatial structure of tourism, problems connected with its development should be looked upon at local and regional levels. The bulk of tourism consumption takes place in specific towns or tourism regions, with all the positive and negative implications it brings for these destinations. The growing importance of tourism for local and regional economies of numerous territorial units, the high volatility of macro- and micro-environments of tourism entities and a risk, higher than in other areas of activity, make an increasing number of municipalities or regions take advantage of strategic management concepts for tourism destina- tions. The prime stage of this concept is a strategic analysis, and its quality determines, to a large extent, the success of the entire process. The most popular method of strategic analysis in the Polish economic situation is SWOT analysis. The review of tourism development strategies of many gminas, powiats and województwos, however, shows that the application of this analysis to the strategic management of tourism destinations leads to a number of problems and methodological mistakes.

The aim of the paper is to identify the role of SWOT analysis in the formulation of tourism development strategies for destinations. The research material is composed of secondary data collected from the literature, bibliographic studies and documents. A descriptive approach, an inductive research method, was employed. The paper outlines the concept of a tourism development strategy as an instrument used in the strategic management of a destination, describes SWOT analysis and presents the most important problems and methodological mistakes resulting from the application of SWOT analysis as a strategic planning tool in destinations. 


\section{A TOURISM DEVELOPMENT STRATEGY AS AN INSTRUMENT FOR THE STRATEGIC MANAGEMENT OF DESTINATIONS}

Tourism destination management may be defined as a process of meeting objectives, using human, material, natural and information resources, and involving activities connected with planning, organization, motivation and control. The complexity of this process is mainly caused by the need to simultaneously meet the needs of the tourism economy of a given area (local or regional), autonomous economic and social entities (enterprises, organizations and associations), and a territorial unit which comprises such entities (gmina, powiat or województwo). In business practice there are two approaches to tourism destination marketing: a spontaneous approach and a planning approach. The spontaneous approach, based on a game of market forces, is the older and the most common and brings a spontaneous development of tourism and tourism products. The consequences of this model are disturbances of tourism-related and other functions held by a territorial unit (dominance of tourism or insufficient development of tourism). Other problems which may appear include a lack of a clear tourism product or a coherent image of a destination, insufficient coordination of activities carried out by various economic and social entities, exceeding the limits of tourism absorptiveness, and inadequate flexibility of tourism products. In the planning approach, the tourism-related function may either be regarded as an isolated area of activity or may be integrated. This approach clearly helps to avoid many of the mistakes made in the spontaneous approach, but it also has some constraints, mainly due to the 'bureaucratism' typical of the public sector. The implementation of this concept brings particularly small results when there is a dominance of a technocratic or any other point of view, focused on the expansion of tourism (DzIEDZIC 1998). Nevertheless, both concepts, due to many endogenous and exogenous changes, have failed when used as methods for tourism destination management. Therefore, the strategic management concept has appeared against this background, and its main assumptions are presented in Table 1.

The strategic management of tourism destinations is an extension of traditional planning methods. In the literature there are various definitions of strategic management, most of which emphasize the following features:

They

- concern strategic goals (fundamental and overriding) of a tourism destination,

- show a long time horizon,
T a b l e 1. Key determinants of the strategic management of tourism destinations

\begin{tabular}{|c|c|}
\hline Assumption & Description \\
\hline $\begin{array}{l}\text { Hyper- } \\
\text { competition }\end{array}$ & $\begin{array}{l}\text { Rapid structural changes in competition } \\
\text { and the environment lead to problems } \\
\text { in anticipation of these changes. As a } \\
\text { consequence, the planning time horizon } \\
\text { is reduced and guidelines for strategies } \\
\text { are changed (development paths instead } \\
\text { of detailed strategies). }\end{array}$ \\
\hline Globalisation & $\begin{array}{l}\text { Due to the dynamic flow of people, } \\
\text { capital, knowledge and information, the } \\
\text { authorities of a given area have to focus } \\
\text { primarily on the macro-environment, } \\
\text { instead of their competitors. }\end{array}$ \\
\hline $\begin{array}{l}\text { Technological } \\
\text { progress }\end{array}$ & $\begin{array}{l}\text { Intense development of modern } \\
\text { technologies leads to specific changes in } \\
\text { the way organisations operate. The best } \\
\text { example is the growth of the internet } \\
\text { which has contributed to changes in the } \\
\text { possible areas of distribution. The } \\
\text { internet allows an entity to enter } \\
\text { international markets straight away, } \\
\text { without having to enter local, regional } \\
\text { and national markets first. }\end{array}$ \\
\hline $\begin{array}{l}\text { Primacy } \\
\text { of market } \\
\text { value }\end{array}$ & $\begin{array}{l}\text { The evaluation of tourism destinations } \\
\text { in terms of the stakeholder value they } \\
\text { generate (for local communities, } \\
\text { authorities at all levels, tourists, enter- } \\
\text { prises, institutions etc.). This implies } \\
\text { the use of good practice in management } \\
\text { for example through the implementation } \\
\text { of the relationship marketing concept. }\end{array}$ \\
\hline Concentration & $\begin{array}{l}\text { Strong integration tendencies of various } \\
\text { entities (e.g. the establishment of } \\
\text { associations or unions of municipalities) } \\
\text { may contribute to a synergy effect. }\end{array}$ \\
\hline $\begin{array}{l}\text { Activation of } \\
\text { communities }\end{array}$ & $\begin{array}{l}\text { Today's local communities are increa- } \\
\text { singly active manifested by increased } \\
\text { social control of local authorities, the } \\
\text { articulation of needs and, possibly, } \\
\text { dissatisfaction. Nowadays the } \\
\text { authorities' task is not limited to the } \\
\text { provision of collective services but also } \\
\text { involves responsibility for the develop- } \\
\text { ment of their tourism destination. }\end{array}$ \\
\hline $\begin{array}{l}\text { Changes } \\
\text { in tourism } \\
\text { demand }\end{array}$ & $\begin{array}{l}\text { The twilight of a mass tourism based } \\
\text { on product unification. Due to economic } \\
\text { changes (higher earnings, higher net } \\
\text { disposable income), social changes } \\
\text { (better educated people, changes in life- } \\
\text { styles), or demographic changes (ageing } \\
\text { populations and the increasing } \\
\text { participation of the elderly in tourism), } \\
\text { there is a clearer segmentation } \\
\text { of tourism markets. }\end{array}$ \\
\hline
\end{tabular}

S o u r c e: authors, based on DZIEDZIC (1998); ROMANOWSKA (2007); STRUŻYCKI (2004). 
- are connected with the creation of rational strategic plans,

- involve the adjustment of the tourism destination to its volatile environment,

- assume that various social groups (authorities, inhabitants, entrepreneurs, organizations and associations) should participate in the creation and implementation of plans,

- bring about structural changes in the tourism destination,

- are connected with the need to make choices in conditions of uncertainty and risk.

The key aim of the strategic management of a given territorial unit is to maintain its presence on the market and maintain opportunities for development. With reference to tourism destinations, the main aim will be to ensure their economic and social lifespan by creating a tourism product that is competitive and will contribute to the possibility of generating income from tourism in the long run (DZIEDZIC 1998; KORNAK \& RAPACZ 2001; MEYER \& MILEWSKI 2009). Strategic management may be carried out at three levels represented by the following strategies (BEDNARSKA, GOŁEMBSKI, MARKIEWICZ \& OLSZEWSKI 2007): general strategies (basic, development, leading), formulated at the level of a destination as a whole; operating areas strategies, specifying the scope of individual domains and methods used to gain a long-lasting competitive advantage in a given sector or market segment; and functional strategies concerning the specific functions to be performed, i.e. marketing, finance or investment. The development strategy, however, continues to be the basic instrument in strategic management of tourism destinations and it is defined, according to STRUŻYCKI (2004, pp. 225), as 'identifying long-term objectives and conditions for development, and making decisions on the allocation of resources needed to meet the objectives'. The stages followed in the formulation of a leading strategy are presented in Fig. 1.

Stage one of the strategic planning process is aimed at establishing the main directions for the development of a tourism destination. During this stage, the basic attributes, such as a mission, a vision and strategic objectives, are usually formulated. The mission is defined as the reasons behind a territorial unit's operation, specifying the key values to be followed in this operation. The mission communicates the values the organization believes in to its stakeholders. The mission is further specified and expanded on in the vision, which is the representation of a desirable future. The vision also systemizes the values and the objectives, stimulates motivation and the involvement of entities which implement the strategy. The mission and the vision are further crystallized in the

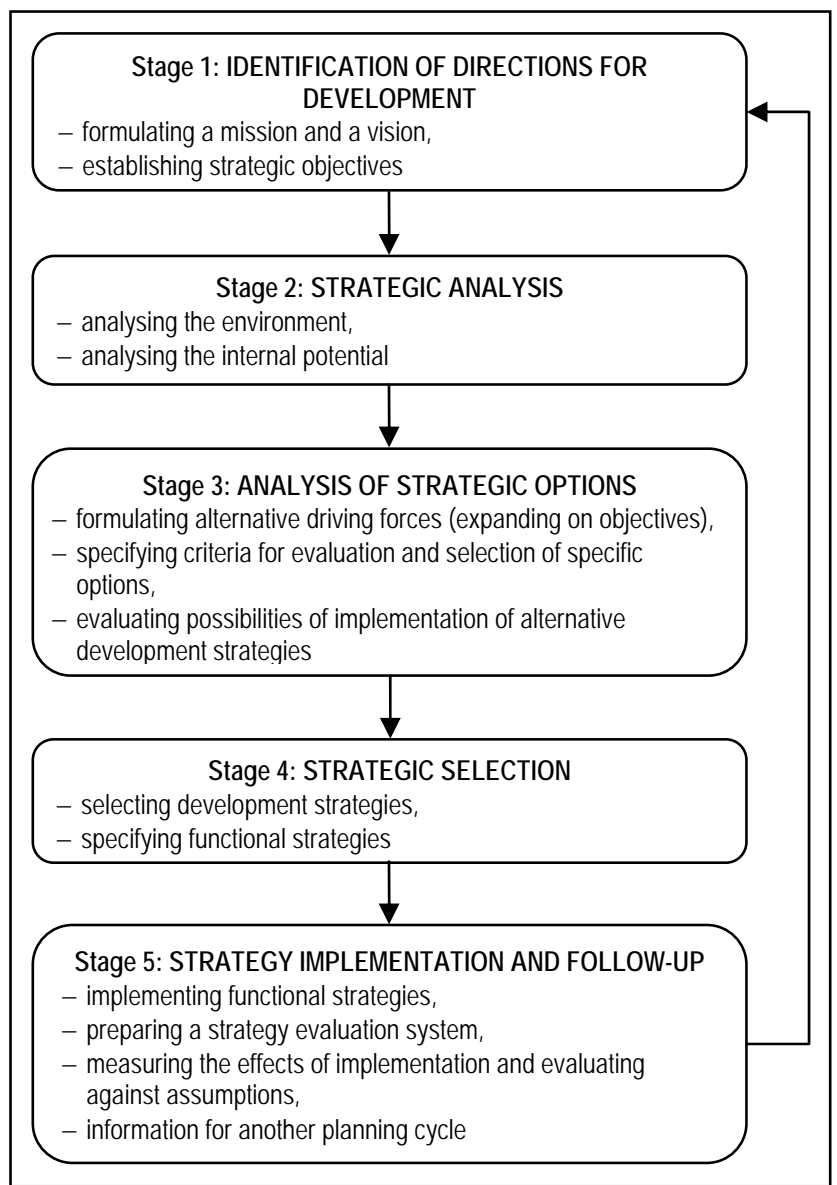

Fig. 1. Stages in the planning of a leading strategy for a tourism destination

S o u r c e: authors, based on ROMANOWSKA (2007)

strategic objectives which represent a desirable state which the territorial unit is heading for within a specified time. Consequently, the strategic objectives mark the development path for the tourism destination (ROMANOWSKA 2007; STABRYŁA 2000). In some authors' concepts (SUPERNAT 1998), the strategy planning process begins with a strategic analysis, and the directions for an organization's development are identified at stage two. GOŁĘBIOWSKI (2001) advocates the simultaneous implementation of both stages. Stage two of the strategy formulation process is a strategic analysis and its correctness determines the quality of the subsequent stages of strategic management. Analytic work concerning the environment and internal resources is carried out simultaneously. The analysis of the environment comprises its more remote aspect (macro-environment) as well as the closer (competitive environment). The subject matter in the analysis of the macro-environment involves, in broad terms, economic, social, demographic, natural, technological, political and legal trends, analyzed from national and international perspectives. The interaction 
between the tourism destination and its macroenvironment is a one-way interaction. The macroenvironment is essential for the functioning of the tourism destination, but the tourism destination has practically no impact on the situation in the macroenvironment. The most popular methods for the analysis of the more remote environment are a trend analysis, a strategic gap analysis, the Delphi method and scenario methods. The aim of the analysis of the competitive environment, which may be somehow affected by the tourism destination, is the identification of its attractiveness in terms of market growth and the type of competition, and is the analysis most often carried out for the most important products or segments of the tourism market. The subject matter of competition analysis for the tourism destination is the evaluation of its prospects in terms of (DZIEDZIC 1998) a forecast pace of growth in tourism demand, its structure, the profitability of factors affecting the demand, the type of competition and its determinants, and the position of a competitive tourism destination. The most popular methods used to analyze the closer environment are Porter's 'five forces' analysis, a sector economic profile, a score assessment of sector attractiveness, and a strategic group map. The internal analysis of the tourism destination potential should focus on the key success factors which are the source of the destination's competitive advantage. According to DZIEDZIC (1998), the most essential factors determining the success of the tourism area on the market are a set of tourism products and their availability, competences in provision of services and the level of technologies, marketing, the level of organization and management, the level of costs, profitability and financial resources. These factors can be evaluated using the following methods for analyzing the area's internal potential: a strategic balance, an analysis of key success factors, a score assessment of potential, a competitive profile, a value chain, and the lifecycles of a tourism product and a destination. The logical conclusion of strategic analysis results in the analysis of strategic options (stage 3 ) which the destination can choose from. This concerns concrete products, as well as the conditions in which activities are performed. Such analyses are conducted using integrated (portfolio) methods, such as McKinsey's, ADL, Hofer's and BCG matrices or SWOT analysis. The most popular and important, for the needs of this paper, is SWOT analysis. It may be carried out for the most important tourism products, as well as for the entire destination. When conducting the analysis, one should remember to take into account only those factors which are most relevant for the competitiveness of the destination. A particular emphasis is placed on the attributes which are important for potential tourists. It is also advisable to present the selected issues in order of priority, i.e. from the most relevant to those with secondary importance (DZIEDZIC 1998). An analysis carried out in this way may constitute a valuable instrument which helps to make strategic choices and select the appropriate leading strategy (stage 4). A detailed description of SWOT analysis will be presented in the following section. Once selected, the development strategy for the destination should be translated into functional strategies (e.g. marketing, financial, personal etc). Functional strategies are then translated into operational and tactical plans, and these plans, in turn, into the budgeting of activities. An effective procedure for the implementation of the leading strategy may be a balanced scorecard (BSC) which allows the strategy to be implemented in four main perspectives: financial, learning and growth, customer (tourists and visitors), and internal business processes (KAPLAN \& NORTON 1992). The implementation of the functional strategies is the first task at the last stage of the development strategy planning process. Next, the criteria for evaluation of the strategy implementation are formulated, the effects are measured and compared with accepted assumptions. This stage should reveal any faults in operation and management as well as indicating ways of removing these negative phenomena (corrective actions) and protecting against them in the future (preventive actions). If this stage goes through properly, the parties that manage the tourism destination obtain the complete set of data needed to perform the next strategic planning cycle. The strategic management process is progressive and concerns subsequent time horizons.

\section{DESCRIPTION OF SWOT ANALYSIS}

SWOT analysis is one of the most frequently used methods in strategic management. It is employed to build an overall development strategy (general) as well as functional strategies (fractional), concerning a function to be performed by a state, a local government unit or an enterprise (marketing, finance, logistics, etc.). GIERSZEWSKA \& ROMANOWSKA (2002, pp. 235) claim that SWOT is not a method of strategic analysis but is 'a unique algorithm of a strategic analysis process, a systemic proposal and a wide-ranging evaluation of external and internal factors which specify a company's current status and its development potential'. The term 'SWOT' is an acronym, standing for strengths, weaknesses, opportunities and threats. This method is wide-ranging because it concerns internal factors (the organization as such), 
external factors (the closer environment - the competitive environment, and the more remote environment - the macro-environment). The combination of external and internal factors leads to four categories (GIERSZEWSKA \& ROMANOWSKA 2002): external positive - opportunities; external negative - threats; internal positive - strengths; and internal negative - weaknesses. The SWOT analysis model is presented in fig. 2.

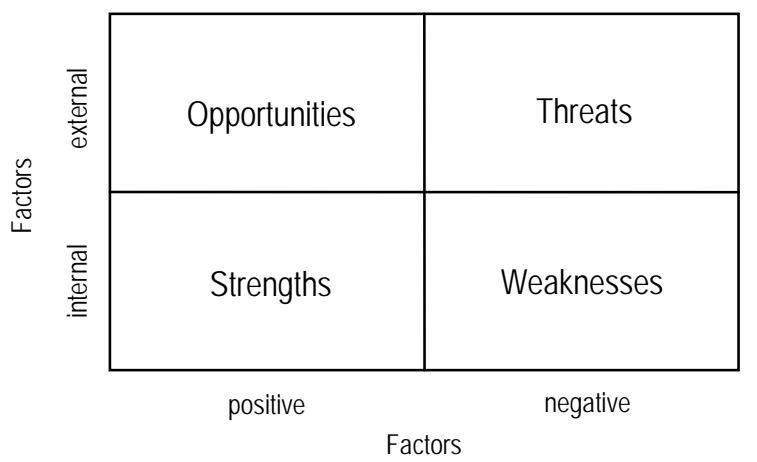

Fig. 2. Factors affecting the strategic position of an organization in SWOT analysis

Source: GIERSZEWSKA \& ROMANOWSKA (2002, pp. 236)

Strengths (internal positive factors) are the most important resources, skills and competences which improve the competitive position. In the case of a tourism destination, these may include unique tourism advantages (natural and anthropogenic), a well-developed tourism infrastructure, highly qualified human resources and a destination brand. Weaknesses (internal negative factors) which hinder development may include the poor financial standing of a local government unit, a poorly developed technical infrastructure, incompetent gmina, powiat and województwo authorities, etc. Opportunities (external positive factors) are certain events and circumstances which can be used to achieve success. Examples of such factors may be positive changes to tourism legislation, an accelerated pace of economic growth (an increase in personal earnings and disposable incomes), an improved situation on the tourism market, better transport connections to the area, programs aimed at obtaining external sources of finance for investments in kind or in people (the state, the EU). Threats (external negative factors) are barriers or risks which hinder development and the achievement of objectives, e.g. changes in tourist preferences, the dynamic development of tourism in neighbouring areas (which may also be a positive factor), economic recession, difficulties in cross-border traffic, appreciation of the national currency (concerns foreign tourists and a floating exchange rate) or negative unpredictable events (e.g. flood, a terrorist attack, a war).

In SWOT analysis, there is no need to specify all the factors. Instead, those which are of prime importance and may determine the future should be in focus. In business practice, the four-field SWOT matrix is often divided into smaller parts. Depending on the accepted methodological variant of the analysis, opportunities and threats, for example, may be divided into more remote (macro-environment) and closer (sectoral environment), and strengths and weaknesses into economic, social, legal, spatial, environmental, political, organizational etc. (GIERSZEWSKA \& ROMANOWSKA 2002). The essence of SWOT analysis is the ability to take advantage of strengths and weaknesses, opportunities and threats, and to ensure compatibility between the destination's resources and conditions in its environment. Consequently, strengths should be used, weaknesses should be eliminated, opportunities should be seized and threats should be neutralized (GOŁĘBIOWSKI 2001; STRUŻYCKI 2004).

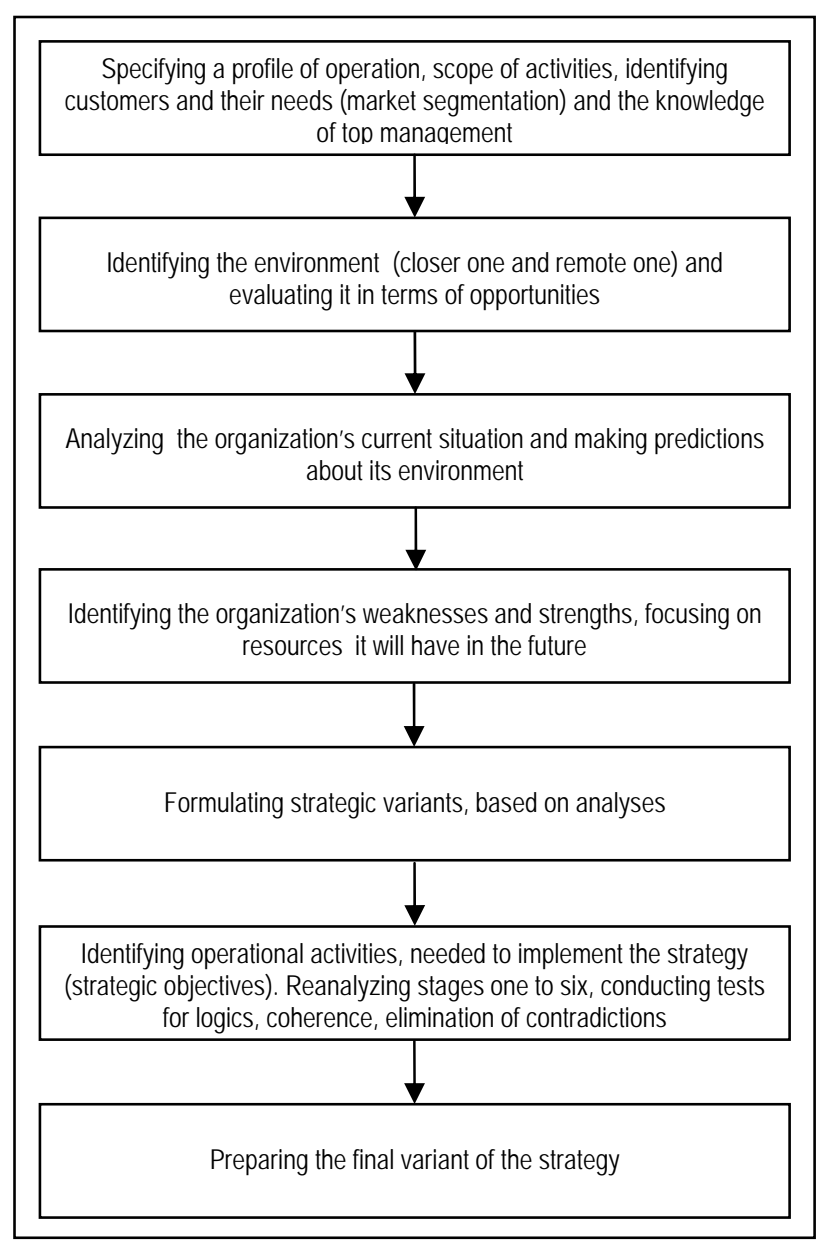

Fig. 3. Algorithm of a procedure in SWOT analysis, according to Weihrich

Source: authors, based on WEIHRICH (1982) 
WEIHRICH (1982), based on the observations of enterprises and studies of their strategies, stated that SWOT analysis should also include analysis of the organization's current situation and design of the strategy for the four types of strategic situation. The flow of analytical activities, according to the author's idea, is presented in Fig. 3.

WEIHRICH (1982) also distinguished four model strategic variants of an organization, depending on the combination of internal and external factors:

1. SO (strengths-opportunities) situation - a maximaxi (expansive) strategy. This concerns an organization dominated by strengths inside and opportunities in its environment. In this situation, the strengths should be used to take advantage of the opportunities from the environment, through strong market expansion and attempts to achieve diversified development. A tourism destination with unique tourism advantages, for example in conditions of fast growing domestic tourism demand, may carry out an aggressive strategy of market penetration by expanding its modern tourism infrastructure and undertaking intense promotional activities.

2. WO (weaknesses-opportunities) situation - a minimaxi (competitive) strategy. This refers to an organization which is dominated by weaknesses, but operates in a favourable environment. Its strategy, consequently, should be focused on taking advantage of the opportunities and, at the same time, eliminating the weaknesses. With a growing tourism demand, a tourism destination which has some tourism advantages but a poor accommodation base, may try to find some strategic partners for cooperation (e.g. the establishment of an association of tourism municipalities).

3. ST (strengths-threats) situation - a maxi-mini (conservative) strategy. In this situation, an organization has great internal potential but operates in adverse external conditions. Therefore, it needs to overcome the threats, making the best use of its strengths. For example, in conditions of diminishing domestic demand for tourism services, the destination may try to attract visitors or stimulate some type of tourism (business, ethnic, health), with lower income flexibility of tourism demand, by launching innovative tourism products.

4. WT (weaknesses-threats) situation - a mini-mini (defensive) strategy. This concerns an organization without any prospects for development and with a small internal potential, operating in an adverse external situation. Its aim is to minimize the weaknesses and avoid the threats. In a worst-case scenario, the destination should change its dominant functions, e.g. from tourism to an industrial function, and in a best-case scenario, it should strive to survive the difficult time, trying to find some external sources of finance for tourism investments or establish an association of tourism municipalities.

The assessment of the environment leads to the distinction of four typical strategic situations and related activities. They are described in Table 2.

T a b l e 2. Division of undertakings by opportunities and threats

\begin{tabular}{|l|l|l|}
\hline \multirow{2}{*}{ Threats } & \multicolumn{2}{|c|}{ Opportunities } \\
\cline { 2 - 3 } Small & $\begin{array}{l}\text { Big } \\
\text { Perfect chances } \\
\text { - great opport- } \\
\text { unities are } \\
\text { accompanied by } \\
\text { a low risk of } \\
\text { threats }\end{array}$ & $\begin{array}{l}\text { Stable undertakings - give } \\
\text { a chance to obtain some } \\
\text { small benefits, with low } \\
\text { threats and limited opport- } \\
\text { unities for development }\end{array}$ \\
\hline Big & $\begin{array}{l}\text { Speculative } \\
\text { undertakings - } \\
\text { aggregation } \\
\text { of opportunities } \\
\text { and threats }\end{array}$ & $\begin{array}{l}\text { Problematic undertakings } \\
\text { - changes in the environ- } \\
\text { ment do not create any } \\
\text { opportunities and pose } \\
\text { numerous threats }\end{array}$ \\
\hline
\end{tabular}

S o u r c e: authors, based on GOŁĘBIOWSKI 2001; KOTLER 2005; NIESTRÓJ 1998.

Similarly, the analysis of the organization's strengths and weaknesses can be used to distinguish the following situations (Table 3).

T a b l e 3. Division of undertakings by strengths and weaknesses

\begin{tabular}{|c|c|c|}
\hline \multirow{2}{*}{ Weaknesses } & \multicolumn{2}{|c|}{ Strengths } \\
\hline & Big & Small \\
\hline Small & $\begin{array}{l}\text { Absolute advantage - } \\
\text { the resultant } \\
\text { of strengths and } \\
\text { weaknesses is better } \\
\text { than competitors' }\end{array}$ & $\begin{array}{l}\text { Average position } \\
\text { - the resultant } \\
\text { of strengths and } \\
\text { weaknesses is } \\
\text { similar to } \\
\text { competitors' }\end{array}$ \\
\hline Big & $\begin{array}{l}\text { Partial advantage - } \\
\text { the organization's } \\
\text { strengths are bigger } \\
\text { than the competitors' }\end{array}$ & $\begin{array}{l}\text { Weak position - } \\
\text { the organization's } \\
\text { strengths are } \\
\text { smaller than } \\
\text { the competitors' }\end{array}$ \\
\hline
\end{tabular}

S o u r c e: authors, based on GOŁĘBIOWSKI 2001; NIESTRÓJ 1998.

The conditions presented in Tables 2 and 3 may be aggregated and presented in the form of a matrix, showing the combinations of variants of situations and corresponding strategic options (Table 4). 
$\mathrm{T}$ a b l e 4. Variants of an organization's strategic situations

\begin{tabular}{|l|l|l|l|l|}
\hline \multirow{2}{*}{\begin{tabular}{c} 
Division of $\begin{array}{c}\text { undertakings } \\
\text { by opportunities } \\
\text { and threats }\end{array}$ \\
\cline { 2 - 5 }
\end{tabular}} & Absolute advantage & \multicolumn{1}{|c|}{ Partial advantage } & Average position & \multicolumn{1}{|c|}{ Weak position } \\
\hline Perfect chances & Investments & $\begin{array}{l}\text { Investments } \\
\text { and elimination } \\
\text { of weaknesses }\end{array}$ & $\begin{array}{l}\text { Investments } \\
\text { and building } \\
\text { a competitive } \\
\text { advantage }\end{array}$ & $\begin{array}{l}\text { Elimination } \\
\text { of weaknesses } \\
\text { and copying } \\
\text { the leader }\end{array}$ \\
\hline $\begin{array}{l}\text { Speculative } \\
\text { undertakings }\end{array}$ & $\begin{array}{l}\text { Investments } \\
\text { and neutralization } \\
\text { of threats }\end{array}$ & $\begin{array}{l}\text { Using chances } \\
\text { to balance } \\
\text { opportunities } \\
\text { and threats }\end{array}$ & $\begin{array}{l}\text { Using chances } \\
\text { and building one's } \\
\text { position in market } \\
\text { niches }\end{array}$ & $\begin{array}{l}\text { Withdrawal from } \\
\text { the market }\end{array}$ \\
\hline Stable undertakings & $\begin{array}{l}\text { Taking advantage } \\
\text { of the position }\end{array}$ & $\begin{array}{l}\text { Using one's position } \\
\text { as needed }\end{array}$ & $\begin{array}{l}\text { Maintaining one's } \\
\text { position }\end{array}$ & $\begin{array}{l}\text { Elimination of weak- } \\
\text { nesses and copying } \\
\text { the leader as needed }\end{array}$ \\
\hline $\begin{array}{l}\text { Problematic } \\
\text { undertakings }\end{array}$ & $\begin{array}{l}\text { Withdrawal from } \\
\text { the market }\end{array}$ & $\begin{array}{l}\text { Withdrawal from } \\
\text { the market }\end{array}$ & $\begin{array}{l}\text { Withdrawal from } \\
\text { the market }\end{array}$ & $\begin{array}{l}\text { Withdrawal from } \\
\text { the market }\end{array}$ \\
\hline
\end{tabular}

S o u r c e: authors, based on GOŁĘBIOWSKI 2001; NIESTRÓJ 1998.

In business practice, so-called SWOT scoring and the probability of strategic success are also used. This involves the evaluation on an accepted scale of key internal and external factors, and determining whether there are more strengths than weaknesses in the organization and more opportunities than threats in its environment. This procedure helps to choose the right strategy and may be combined with the assessment of the probability of strategic success using an algorithm constructed by BERLIŃSKI (2002). Within this procedure, the following stages may be distinguished (BERLIŃSKI 2002; BERLIŃSKI \& PENC-PIETRZAK 2004):

1. A list of strengths and weaknesses in the form of a table, and their evaluation on an accepted scale, e.g. 1-5 points, summarizing strengths and weaknesses and proving advantage or balance.

2. Similar to item 1 , the same procedure for threats and opportunities.

3. Identification of an organization's strategic position, with one of the four strategies (SO, WO, ST, WT), as described above, ascribed to it.

4. Assessment of the probability of strategic success (PSS), according to the formula:

$$
P S S=\frac{S P+A S}{2}
$$

where:

PSS - coefficient of probability of a strategic success,

SP - the organization's internal strength,

AS - the organization's attractiveness in the environment,

$0<$ PSS $\leq 1$,

PSS $>0.5 \rightarrow 1$.
The probability of strategic success ranges from zero to one. The condition for achieving the success is to have a co-efficient value which exceeds 0.5 . The internal strength (SP) is calculated taking into account the list of strengths (S) and weaknesses (W), and the external strength (AS) by evaluating opportunity $(\mathrm{O})$ and threats $(\mathrm{T})$.

$$
\begin{gathered}
S P=\frac{\sum S}{\sum S+W} \\
A S=\frac{\sum O}{\sum O+T}
\end{gathered}
$$

\section{SWOT ANALYSIS AS AN INTEGRATED STRATEGIC PLANNING TOOL FOR TOURISM IN DESTINATIONS}

The application of SWOT analysis enables the entities which are responsible for management of local or regional tourism policies in destinations, to position tourism in the overall and general strategic planning in a methodical and orderly way. The local government units are obliged, by law, to pursue a tourism policy where planning is an important function. The identification of objectives and methods to be employed in the development of tourism, i.e. functional planning, should always be preceded by SWOT strategic positioning as an integrated tool which can be used to carry out such activities as planning, coordination, monitoring, control and promotion. 
It should be clearly emphasized, however, that SWOT analysis may only be helpful on condition that it is carried out completely and used fully. No management method, technique or tool, if used just partially, can fulfil its tasks. Nevertheless, a review of tourism development strategies at the regional level (e.g. Województwo pomorskie) or the local level (e.g. Kraków and Wrocław) shows that SWOT analysis tends to be used in an improper way, i.e. partially. It is, most frequently, a detailed specification of individual fields from a matrix without further scaling. Such an approach is a serious methodological mistake and threatens the value of the strategic analysis of the destination. Only a comparison of positioning factors on an appropriate scale can lead to a correct formulation of problems whose identification serves to establish the conclusions needed as a basis for improvement.

The SWOT framework, when used partially, is deprived of the attributes of completeness which integrate all tasks connected with planning, coordination and task monitoring concerning tourism. The completeness postulate is so vital because the integrated planning function determines the position and the status of the tourism economy within the entire spectrum of social and economic activities carried out by local government units.

SWOT analysis is also an important element of place marketing used by local governments to stimulate processes related to the development of business activity connected with tourism. The place marketing process concerning tourism may include the following elements (SZROMIK 2008):

- making an inventory of areas and places which may be attractive for tourism-related development, and business activities connected with such development,

- developing a concept for giving access to investment advantages, by preparing profitability analyses and estimates for undertakings,

- preparing offers containing a complete description of advantages, including possibilities of cofinancing and/or external financing of undertakings,

- soliciting offers by an active search for investors, presenting development opportunities to external entities,

- a logistic and information service, as well as the organization and coordination of activities aimed at entities which are willing to operate in tourism.

The guidelines resulting from a correct SWOT analysis at local or regional levels determine the directions for the strategic behaviour of economic entities dealing with tourism services. Properly specified directions for activities are also important for those entities operating on the tourism services market which are planning to carry out specific tourism, or semi-touristic, investments in a given tourism destination. Tourism enterprises, when creating their own strategic or investment plans, carefully analyze local or regional strategies for tourism development, and the conclusions drawn from these analyses are important assumptions for making business decisions. This may be of major importance not only for the future of these economic entities, but also for the entire local or regional economy of the tourism area, as well as for the quality of its inhabitants' lives.

\section{CONCLUSIONS}

Due to the growing importance of tourism for the local and regional economies of numerous destinations, a well-run tourism policy becomes a priority. It should be oriented towards making the best use of advantages, and removing any possible disruptions which may be caused by the development of tourism. Specific operational or tactical activities should result from strategic plans and, most of all, from local and regional strategies for tourism development. Such strategies have to be based on reliable analyses of the internal potential and the environment of a destination by making use of a complete SWOT analysis. A partial approach to SWOT analysis, which can often be seen in tourism development strategies implemented by Polish gminas, powiats and województwos, should be regarded as a serious methodological mistake that distorts the meaning of this analysis. The analysis has to be complete to ensure that strategic options are properly formulated, the right strategic choice is made and strategic plans are correctly implemented and inspected, as it provides a starting point for subsequent planning cycles.

\section{BIBLIOGRAPHY}

BEDNARSKA M., GOŁEMBSKI G., MARKIEWICZ E., OlSZEWSKI M., 2007, Przedsiębiorstwo turystyczne. Ujęcie statyczne $i$ dynamiczne, PWE, Warszawa.

BERLIŃSKI L., 2002, Zarządzanie strategiczne małym przedsiębiorstwem, OPO, Bydgoszcz.

BERLIŃSKI L., PENC-PIETRZAK I., 2004, Inżynieria projektowania strategii przedsiębiorstwa, Diffin, Warszawa.

DZIEDZIC E., 1998, Obszar recepcji turystycznej jako przedmiot zarzadzania strategicznego, SGH, Warszawa.

GIERSZEWSKA G., ROMANOWSKA M., 2002, Analiza strategiczna przedsiębiorstwa, PWE, Warszawa.

GOŁĘBIOWSKI T., 2001, Zarządzanie strategiczne. Planowanie i kontrola, Diffin, Warszawa. 
KAPLAN R., NORTON D., 1992, The balanced scorecard - measures that drive performance, Harvard Business Reviev, 70 (1), pp. 71-80.

KORNAK A., RAPACZ A., 2001, Zarządzanie turystyka i jej podmiotami w miejscowości i regionie, AE, Wrocław.

KOTLER PH., 2005, Marketing, Rebis, Poznań.

MEYER B., MILEWSKI D., 2009, Strategie rozwoju turystyki w regionie, Wyd. Naukowe PWN, Warszawa.

NIESTRÓj R., 1998, Zarzadzanie marketingiem. Aspekty strategiczne, Wyd. Naukowe PWN, Warszawa-Kraków.

ROMANOWSKA M., 2007, Planowanie strategiczne w przedsiębiorstwie, PWE, Warszawa.
STABRYŁA A., 2000, Zarządzanie strategiczne w teorii i praktyce fir$m y$, Wyd. Naukowe PWN, Warszawa-Kraków.

STRUŻYCKI M., 2004, Zarządzanie przedsiębiorstwem, Diffin, Warszawa.

SUPERNAT J., 1998, Zarzadzanie strategiczne: pojęcia $i$ koncepcje, Kolonia Limited, Wrocław.

SZROMIK A., 2008, Marketing terytorialny, Wyd. Oficyna Ekonomiczna, Kraków.

WEIHRICH H., 1982, The TOWS matrix. A tool for situational analysis, Long Range Planning, 15 (2), pp. 54-66. 